623.4 .022

\author{
. . шков ${ }^{1},$. . улеко ${ }^{2}$, . . ум кевич ${ }^{3}$ \\ 1 ищ, тест иійн комісія, иїв \\ 2 итомирський військовий інститут ціон льного ві ційного університету, итомир \\ 3 ввівський інститут ухопутних військ, ввів
}

озгляд ються способи використ ння ртилерійських систем для з пуску псевдосупутникових систем спостереження, вимоги $m$ вл стивості їх $n$ р тури.

лючові слов : ртилерійськ розвідк, псевдосупутников систем, зон огляду, розрізнюв льн зд тність, фото $n$ р тур .

\section{сту п}

сьогодні скл д р кетних військ і ртилерії пр ктично відповід є пок зник м, які визн чені у перспективній моделі бройних ил кр їни 2015 року. обто, кількісне реформув ння р кетних військ і ртилерії бройних ил кр їни з кінчено, і н сьогодні пост є пит ння щодо їх якісного розвитку.

йв жливішими н прямк ми под льшого розвитку р кетних військ і ртилерії з лиш ються: проведення орг ніз ційних 3 ходів із метою створення у р кетних військ х $\mathrm{i}$ ртилерії орг ніз ційних структур, які 6 функціон льно відповід ли х р ктеру можливих дій 3 призн ченням; розробк і втілення нових способів бойового з стосув ння р кетних військ і ртилерії відповідно до суч сних умов збройної боротьби; відпр цюв ння суч сної концепції вогневого ур ження противник в опер ціях і іiі пр ктичн ре ліз ція згідно 3 економічними можливостями держ ви; теоретичне обгрунтув ння нових форм вогневого ур ження; створення єдиної методики опер тивно-т ктичних розр хунків під ч с пл нув ння вогневого ур ження противник в опер ції 3 лок ліз ції (нейтр ліз ції) збройного конфлікту.

перспективі пл нується м ти р кетні комплекси, ртилерійські г рм ти, міномети, високоточні боєприп си, розвід ув льні комплекси, які сконструйов ні т виготовлені н підприємств х кр їни. е дозволить зн чно підвищити рейтинг кр їни як держ ви, що розробляє вл сні зр зКИ озброєння, підвищити ефективність р кетних військ i ртилерії т водноч с скоротити їх чисел ьність 3 p хунок впров дження н йсуч сніших 3 собів озброєння т розвідки [1].

в ж ючи н те, що ефективність 3 стосув нн я p кетно- ртилерійських систем великою мірою визн ч ється якістю результ тів проведення розвідки, можн вв ж ти одним 3 кту льних н прямків вдоскон лення р кетно- ртилерійського озброєння розвиток систем розвідки.

ост новк проблеми. умов х суч сного бою успіх бойових дій з лежить від ефективності і повноти інформ ції розвідки. ля проведення р кетно- ртилерійської розвідки н суч сному ет пі можуть з стосовув тися космічні, ві ційні т н земні технічні з соби розвідки.

опередня розвідк і виявлення ст ціон рних цілей, що підляг ють ур женню, можуть проводитись з вч сно 3 використ нням космічних чи ві ційних з собів розвідки. ерев г ми цих систем $€$ висок точність, дет льність і велик глибин спостереження. дн к використ нню космічних т ві ційних з собів для розвідки рухомих цілей безпосередньо при підготовці чи веденні ртилерійського вогню перешкодж $є$ ряд об'єктивних ф кторів, тому основні 3 д чі 3 розвідки у цей ч с покл д ються н н земні з соби розвідки переднього кр ю.

оловн 3 д ч розвідки переднього кр ю скл д ється у своєч сному і точному визн ченні місцеположення чи координ т цілей. ез цього не можливе ур ження ї вогнем ртилерії т іншими вогневими з соб ми.

н ліз ост нніх досліджень і публік цій . ьогодні існує досить б г то способів визн чення координ т цілей. ороткий н ліз цих способів 3 викл денням їх перев г і недоліків н ведено, н прикл д, в [2].

уч сні з соби ртилерійської р діолок ційної розвідки, т кі як ст нція н земної ртилерійської розвідки $\quad-10$ і $\dddot{1}$ модифік ції, дет льно розглянуті в [3].

[4] н лізується втом тизов ний 6 г тофункціон льний комплекс розвідки й упр вління

(… шков, . . улеко, . . ум кевич 
вогнем ртилерії « ооп рк-1», розроблений « тріл » (м. ул ), що призн чений для визн чен ня координ т вогневих позицій противник (стріляючих мінометів, ртилерії, ре ктивних систем 3 лпового вогню й т ктичних $\mathrm{p}$ кет) 3 пострілом (пуском) і н підст ві отрим них д них здійснюв ти керув ння вогнем вл сних з собів протидії.

уже цік вою суч сною розробкою є комплекс втом тизов ного упр вління вогнем 1126 « пустник- » ( осія) [4]. ін являе собою втом тизов ну систему упр вління ( ) нового покоління й високого інтелекту льного рівня, що з безпечує в ре льному м сшт бі ч су комплексув ння бойових підрозділів з усім вид ми д лекої й ближньої розвідки, прийом і обробку д них про десятки цілей в інтерес х ре ктивної, ствольної т мінометної ртилерії.

н ліз видів і способів ртилерійської розвідки пок зує, що дост тньої, тим більш н длишкової, інформ ції для прийняття рішень ком ндним скл дом н поч ток т в ході ве дення бойових дій не дост тньо.

дним із в рі нтів рішення цієї проблеми є розробк т використ ння для проведення $\mathrm{p}$ кетнортилерійської розвідки псевдокосмічних систем, призн чених для рішення досить широкого спектр 3 вд нь, подібних до з вд нь космічних систем.

ід псевдокосмічною системою будемо розуміти [4] сукупність узгоджено діючих i функціон льно пов'яз них суборбіт льних п р тів і н земних технічних з собів, призн чених для рішення цільових 3 д ч із використ нням н вколоземного простору.

рототипом псевдокосмічної системи $\epsilon$ розроблений держ вним конструкторським бюро « уч» (м. иїв) проект « окіл» [7].

роект « окіл» - це розробк ртилерійського p кетно-космічного комплексу суборбіт льного моніторингу емлі. сновними елемент ми ртилерійського р кетно-космічного комплексу є:

пусков уст новк н б зі 203-мм с мохідної г рм ти 27 « іон»;

контейнер для псевдокосмічного п р т ктивно-ре ктивного сн ряд ;

псевдокосмічний п р т (зонд) 3 цільовою

п р турою, що спуск ється н п р шуті;

3 соби прийому цільової інформ ції.

риблизн б лістичн схем польоту т кої системи н веден н рис.1.

ослідовність опер цій т орієнтовн їх трив лість у ч сі при польоті под ні у т бл. 1. риблизн м с корисного в нТ жу (зонд ) скл д $є$ від 3 до 5 кг. кщо в якості корисного в нт жу використ ти суч сний космічний к дровий фото п р т із вл сною р діолінією перед чі інформ ції, то вже через 2 хв. можн отримув ти знімки підстил ючої поверхні. в ж ючи н бурхливий розвиток н нотехнологій у космічній техніці ре ліз ція цього проекту вже не $\epsilon$ $ф$ нт стикою, як це було $\mathrm{p}$ ніше.

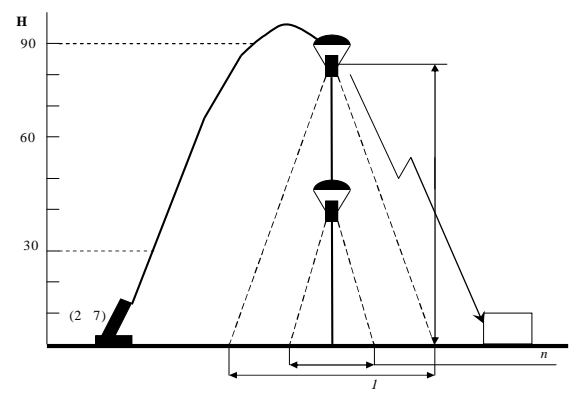

uc. 1. риблизн б лістичн схем п ольоту зонд

блиця 1

ослідовність опер цій т їх орієнтовн трив лість у ч сі при польоті

\begin{tabular}{|c|c|c|c|}
\hline $\begin{array}{l}\text { № } \\
\text { 3/ח }\end{array}$ & $\begin{array}{c}\text { исот } \\
\text { Км }\end{array}$ & $\begin{array}{l}\text { ослідовність } \\
\text { опер цій }\end{array}$ & $\begin{array}{l}\text { с } \\
\text { ВИК., } \\
\text { Хв. }\end{array}$ \\
\hline \multicolumn{4}{|c|}{ ет п польоту (вивід) } \\
\hline 1. & $\begin{array}{l}\text { іля поверхні } \\
\text { емлі }\end{array}$ & остріл & \multirow[t]{8}{*}{2} \\
\hline 2. & ід 0 до 30-35 & $\begin{array}{l}\text { оліт ртилерійської } \\
\text { ч стини }\end{array}$ & \\
\hline 3. & іля 30-35 & $\begin{array}{l}\text { мик ння р кетного } \\
\text { двигун }\end{array}$ & \\
\hline 4. & $\begin{array}{l}\text { ід } 30 \text { до } \\
80-90 \\
\end{array}$ & оліт р кетної ч стини & \\
\hline 5. & $80-90$ & $\begin{array}{l}\text { ідокремлення головної } \\
\text { ч стини }\end{array}$ & \\
\hline 6. & $\begin{array}{l}\text { ід } 80 \text { до } \\
100-110 \\
\end{array}$ & оліт головної ч стини & \\
\hline \multicolumn{3}{|c|}{ ет п польоту (спуск) } & \\
\hline 7. & ід 110 до 90 & $\begin{array}{c}\text { ільне п діння, } \\
\text { розкриття п р шут }\end{array}$ & \\
\hline 8. & $\begin{array}{c}\text { ід } 90 \text { до } \\
\text { поверхні емлі }\end{array}$ & $\begin{array}{l}\text { обоч ділянк , } \\
\text { ст біліз ція т вмик ння } \\
\text { цільової п р тури }\end{array}$ & 50 \\
\hline
\end{tabular}

ет ст тті. po н лізуємо можливості космічних р кетно- ртилерійських систем із ведення ртилерійської розвідки.

ри проведенні н лізу приймемо н ступні обмеження і допущення:

6 зовий в рі нт ртилерійського псевдокосмічного комплексу візьмемо проект « окіл», м ксим льн робоч висот підйому зонд для якого $=90 \mathrm{KM}$.

$\mathrm{x}$ р ктеристики к дрового фото п $\mathrm{p} \mathrm{T}$ візьмемо типові $\mathrm{x}$ р ктеристики суч сного цифрового фото п р т : розміри фотоприйм льної м триці «4/3'’»- $18,0 \times 13,5$ мМ, т «1/1,8'’ $7,2 \times 5,3 \mathrm{мм} ;$ фокусн відст нь фотооб' єктив $f=2-5$ см; об'єктив будемо вв ж ти «іде льним», вплив спотворень не вр ховуємо. основні критерії оцінки якості системи візьмемо н ступні: 
- зон огляду п р тури спостереження;

- просторову розрізнюв льну зд тність.

\section{сновний м тері л}

ксим льн зон огляду, н якій можн спостеріг ти 3 використ нням зонд , $з$ лежить від висоти поч тку робочої ділянки i х р ктеризує гр ничні геометричні можливості спостереження 3 поверхнею емлі.

ксим льн зон огляду визн ч ється центр льним кутом $\psi_{\max }$ (рис. 2).

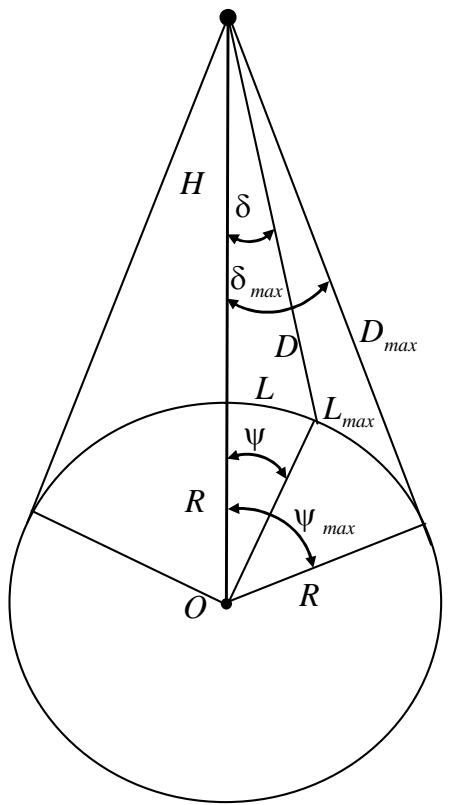

uc. 2. изн чення зони огляду зонду з формулою [8]

$$
\psi_{\text {max }}=\arccos \left(\frac{R_{3}}{R_{3}+}\right)
$$

в лінійних одиницях довжиною дуги н земній поверхні:

$$
L_{\text {max }}=\psi_{\text {max }} \cdot R_{3}=\left(0,5 \pi-\delta_{\text {max }}\right) \cdot R_{3},
$$

де $R_{3}-\mathrm{p}$ діус емлі; $H$-висот польоту зонд .

ід зоною огляду зонд будемо розуміти сукупність точок н поверхні емлі, які зонд може спостеріг ти із з д ної висоти. он огляду з лежить не лише від висоти, й від кут огляду $\delta$ бортової п р тури. кутових величин $\mathrm{x}$

$$
\psi=2\left[\arcsin \left(\frac{R_{3}+H}{R_{3}} \cdot \sin \frac{\delta}{2}\right)-\frac{\delta}{2}\right],
$$

бо в лінійних одиницях

$$
L=\psi \cdot R_{3}=(0,5 \pi-\delta) \cdot R_{3} .
$$

ншим в жливим п р метром є оглядовість, під якою розуміють площу ділянки, що знім ється

$$
S=\pi \cdot H_{P}^{2} \cdot \operatorname{tg}^{2} \gamma
$$

ля прямокутної фотоприйм льної м триці зонд оглядовість буде являти собою проекцію площі прямокутник н емлю і може бути оцінен яK

$$
S \quad=L \quad L \quad,
$$

де $L \quad$ т $\quad L \quad$ - відповідно поздовжня т поперечн ширин смуги огляду.

ід розрізнюв льною зд тністю будемо розуміти розміри н йменших елементів бсолютної міри, які можн розрізнити н знімку [9].

скільки метою ст тті не є точне визн чення розрізнюв льної зд тності конкретного пристрою в конкретних умов х 3 стосув ння, то при розр хунк х використ ємо н ближені формули для розр хунків без визн чення функції перед чі модуляції.

ех й н поверхню емлі н кл ден мір одиничного контр сту. скільки ймовірність точного поп д ння лінії міри н лінію пікселів м триці близьк до нуля, то у н ближених розр хунк х введемо коефіцієнт ст тистичного усереднення 1,5, сутність якого поляг є у тому, що для відобр ження кожних двох ліній міри (чорної т білої) необхідно три ряди пікселів.

ким чином, зн ючи розмір к дру, розр хуємо тепер м ксим льно можливе роз різнення в лініях м триці фотоприйм чів $\mathrm{T}$ приблизні розміри елемент рних фотоприйм чів м триці для різної кількості елементів м триці. езульт ти розр хунків для фотоприйм льної м триці «4/3,'» т «1/1,8', н ведені в т блицях 2 і 3 .

цих т блицях н ближені розміри елемент рного прийм ч под ні без вр хув ння кроку прийм чів. інійну розрізнюв льну зд тність для систем спостереження у першому н ближенні можн визн чити з формулою [7]

$$
R=\frac{H}{f r_{e}} \text {. }
$$

ля фото п р тури $r_{e}$ визн ч ється х р ктеристик ми плівки і об'єктив як кількість ліній в 1 мм. ля м тричних фотоприйм чів $1 / r_{e}$ може розгляд тися як розмір елемент рного прийм ч , тобто $l_{e}=1 / r_{e}$.

езульт ти розр хунків, проведених 3 формул ми (1-7), под ні в т блицях 4-6 для м триці «4/3"'» т т блицях 7-9 для м триці «1/1,8'”. цих т блицях R - теоретичн $\mathrm{T}$ R н ближен до ре льної просторові розрізнюв льні зд тності. 
ля фотоприйм льної м триці «4/3"”

\begin{tabular}{|c|c|c|c|c|}
\hline ег пікселі & $\begin{array}{c}\text { озмір к дру при } \\
4: 3 \text { пікселів } \\
\text { (н ближено) }\end{array}$ & $\begin{array}{c}\text { р ничне } \\
\text { розрізнення } \\
\text { (в лініях пікселів) }\end{array}$ & $\begin{array}{c}\text { ближені розміри } \\
\text { елемент рного } \\
\text { прийм ч (мкм) }\end{array}$ & $\begin{array}{c}\text { квів лентні розміри } \\
\text { елемент рного прийм ч для } \\
\text { гр ничного розрізнення (мкм) }\end{array}$ \\
\hline 3 & $1500 \times 2000$ & $1000 \times 1333$ & 9 & 13,5 \\
\hline 4 & $1700 \times 2350$ & $1134 \times 1566$ & 7,94 & 11,5 \\
\hline 5 & $1900 \times 2600$ & $1266 \times 1733$ & 7,1 & 10,4 \\
\hline 8 & $2450 \times 3250$ & $1633 \times 2167$ & 5,51 & 8,3 \\
\hline
\end{tabular}

блиия 3

ля фотоприйм льної м триці «1/1,8”»

\begin{tabular}{|c|c|c|c|c|}
\hline ег пікселі & $\begin{array}{c}\text { озмір к дру при } \\
4: 3 \text { пікселів } \\
\text { (н ближено) }\end{array}$ & $\begin{array}{c}\text { р ничне } \\
\text { розрізнення } \\
\text { (в лініях пікселів) }\end{array}$ & $\begin{array}{c}\text { ближені розміри } \\
\text { елемент рного } \\
\text { прийм ч (мкм) }\end{array}$ & $\begin{array}{c}\text { квів лентні розміри } \\
\text { елемент рного прийм ч для } \\
\text { гр ничного розрізнення (мкм) }\end{array}$ \\
\hline 3 & $1500 \times 2000$ & $1000 \times 1333$ & 3,6 & 5,4 \\
\hline 4 & $1700 \times 2350$ & $1134 \times 1566$ & 3,1 & 4,6 \\
\hline 5 & $1900 \times 2600$ & $1266 \times 1733$ & 2,8 & 4,1 \\
\hline 8 & $2450 \times 3250$ & $1633 \times 2167$ & 2,2 & 3,3 \\
\hline
\end{tabular}

ля м триці «4/3"”

\begin{tabular}{|c|c|c|c|c|c|}
\hline \multirow{2}{*}{$\begin{array}{c}H, \\
\text { км }\end{array}$} & $L_{\max }$ & \multicolumn{2}{|c|}{ ля $f=2$ см } & \multicolumn{2}{|c|}{ ля $f=5$ см } \\
\cline { 3 - 6 } & 1065 & озміри зони огляду, км & глядовість, км ${ }^{2}$ & озміри зони огляду, км & глядовість, км ${ }^{2}$ \\
\hline 90 & $102,5 \times 68,84$ & 7056,1 & $33,52 \times 24,76$ & 829,96 \\
\hline 80 & 1004 & $91,02 \times 61,17$ & 5567,7 & $29,79 \times 22,01$ & 655,86 \\
\hline 70 & 940 & $79,56 \times 53,50$ & 4256,5 & $26,06 \times 19,26$ & 501,92 \\
\hline 60 & 871 & $68,12 \times 45,83$ & 3122 & $22,34 \times 16,51$ & 368,83 \\
\hline 50 & 795 & $56,71 \times 38,18$ & 2165,2 & $18,61 \times 13,75$ & 255,89 \\
\hline 40 & 712 & $45,32 \times 30,53$ & 1383,6 & $14,89 \times 11,00$ & 163,79 \\
\hline 30 & 617 & $33,96 \times 22,88$ & 777 & $11,17 \times 8,25$ & 92,153 \\
\hline 20 & 504 & $22,62 \times 15,25$ & 345 & $7,44 \times 5,5$ & 40,92 \\
\hline 10 & 356 & $11,30 \times 7.621$ & 86,1 & $3,721 \times 2,75$ & 10,233 \\
\hline 5 & 252 & $5,64 \times 3,81$ & 21,5 & $1,86 \times 1,375$ & 2,56 \\
\hline 1 & 113 & $1,13 \times 0,761$ & 0,86 & $0,372 \times 0,275$ & 0,102 \\
\hline
\end{tabular}

блиия 5

ля м триці «4/3"» фокусн відст нь $f=2$ см

\begin{tabular}{|c|c|c|c|c|c|c|c|c|}
\hline \multirow{2}{*}{$\begin{array}{l}H, \\
\text { км }\end{array}$} & \multicolumn{2}{|c|}{ триця 3 } & \multicolumn{2}{c|}{ триця 4 } & \multicolumn{2}{c|}{ триця 5 } & \multicolumn{2}{c|}{ триця 8} \\
\cline { 2 - 9 } & $\mathrm{R}, \mathrm{M}$ & $\mathrm{R}, \mathrm{M}$ & $\mathrm{R}, \mathrm{M}$ & $\mathrm{R}, \mathrm{M}$ & $\mathrm{R}, \mathrm{M}$ & $\mathrm{R}, \mathrm{M}$ & $\mathrm{R}, \mathrm{M}$ & $\mathrm{R}, \mathrm{M}$ \\
\hline 90 & 40,5 & 68,7 & 35,7 & 51,75 & 31,95 & 46,8 & 24,8 & 37,35 \\
\hline 80 & 36 & 54 & 31,76 & 46 & 28,4 & 41,6 & 22,04 & 33,2 \\
\hline 70 & 31,5 & 47,25 & 27,79 & 40,25 & 24,85 & 36,4 & 19,285 & 29,05 \\
\hline 60 & 27 & 40,5 & 23,82 & 34,5 & 21,3 & 31,2 & 16,53 & 24,9 \\
\hline 50 & 22,5 & 33,75 & 19,85 & 28,75 & 17,75 & 26 & 13,775 & 20,75 \\
\hline 40 & 18 & 27 & 15,88 & 23 & 14,2 & 20,8 & 11,02 & 16,6 \\
\hline 30 & 13,5 & 20,25 & 11,91 & 17,25 & 10,65 & 15,6 & 8,265 & 12,45 \\
\hline 20 & 9 & 13,5 & 7,94 & 11,5 & 7,1 & 10,4 & 5,51 & 8,3 \\
\hline 10 & 4,5 & 6,75 & 3,97 & 5,75 & 3,55 & 5,2 & 2,755 & 4,15 \\
\hline 5 & 2,25 & 3,375 & 1,985 & 2,875 & 1,775 & 2,6 & 1,377 & 2,075 \\
\hline 1 & 0,45 & 0,675 & 0,397 & 0,575 & 0,355 & 0,52 & 0,275 & 0,415 \\
\hline
\end{tabular}


блиия 6

ля м триці «4/3'” фокусн відст нь $f=5$ см

\begin{tabular}{|c|c|c|c|c|c|c|c|c|}
\hline \multirow{2}{*}{$\begin{array}{l}H, \\
\text { км }\end{array}$} & \multicolumn{2}{|c|}{ триця 3 } & \multicolumn{2}{|c|}{ триця 4 } & \multicolumn{2}{|c|}{ триця 5} & \multicolumn{2}{c|}{ триця 8 } \\
\cline { 2 - 8 } & $R, \mathrm{M}$ & $R, \mathrm{M}$ & $R, \mathrm{M}$ & $R, \mathrm{M}$ & $R, \mathrm{M}$ & $R, \mathrm{M}$ & $R, \mathrm{M}$ \\
\hline 90 & 16,2 & 24,3 & 14,3 & 20,7 & 12,78 & 18,72 & 9,92 \\
\hline 80 & 14,4 & 21,6 & 12,7 & 18,4 & 11,36 & 16,64 & 8,82 \\
\hline 70 & 12,6 & 18,9 & 11,12 & 16,1 & 9,94 & 14,56 & 7,714 & 11,62 \\
\hline 60 & 10,8 & 16,2 & 9,53 & 13,8 & 8,52 & 12,48 & 6,612 & 9,96 \\
\hline 50 & 9 & 13,5 & 7,94 & 11,5 & 7,1 & 10,4 & 5,51 & 8,3 \\
\hline 40 & 7,2 & 10,8 & 6,352 & 9,2 & 5,68 & 8,32 & 4,408 & 6,64 \\
\hline 30 & 5,4 & 8,1 & 4,764 & 6,9 & 4,26 & 6,24 & 3,306 & 4,98 \\
\hline 20 & 3,6 & 5,4 & 3,176 & 4,6 & 2,84 & 4,16 & 2,204 & 3,32 \\
\hline 10 & 1,8 & 2,7 & 1,588 & 2,3 & 1,42 & 2,08 & 1,102 & 1,66 \\
\hline 5 & 0,9 & 1,35 & 0,794 & 1,15 & 0,71 & 1,04 & 0,551 & 0,83 \\
\hline 1 & 0,18 & 0,27 & 0,159 & 0,23 & 0,142 & 0,208 & 0,11 & 0,166 \\
\hline
\end{tabular}

ля м триці «1/1,8”’

блиця 7

\begin{tabular}{|c|c|c|c|c|c|}
\hline \multirow{2}{*}{$\begin{array}{l}H, \\
\mathrm{KM}\end{array}$} & \multirow{2}{*}{$\begin{array}{c}L_{\max } \\
\mathrm{KM}\end{array}$} & \multicolumn{2}{|c|}{ ля $f=2 \mathrm{~cm}$} & \multicolumn{2}{|c|}{ ля $f=5 \mathrm{~cm}$} \\
\hline & & озміри зони огляду, км & глядовість, км ${ }^{2}$ & озміри зони огляду, км & глядовість, км ${ }^{2}$ \\
\hline 90 & 1065 & $33,52 \times 24,29$ & 814,2 & $13,03 \times 9,568$ & 124,67 \\
\hline 80 & 1004 & $29,79 \times 21,59$ & 643,17 & $11,58 \times 8,504$ & 98,48 \\
\hline 70 & 940 & $26,06 \times 18,89$ & 492,27 & $10,13 \times 7,441$ & 75,38 \\
\hline 60 & 871 & $22,34 \times 16,19$ & 361,68 & $8,69 \times 6,378$ & 55,42 \\
\hline 50 & 795 & $18,61 \times 13,49$ & 251,05 & $7,24 \times 5,315$ & 38,48 \\
\hline 40 & 712 & $14,89 \times 10,79$ & 151,43 & $5,79 \times 4,252$ & 24,619 \\
\hline 30 & 617 & $11,17 \times 8,1$ & 90,477 & $4,343 \times 3,189$ & 13,85 \\
\hline 20 & 504 & $7,44 \times 5,4$ & 40,18 & $2,86 \times 2,126$ & 6,08 \\
\hline 1 & 356 & $3,721 \times 2,7$ & 10,05 & $1,448 \times 1,063$ & 1,54 \\
\hline 5 & 252 & $1,86 \times 1,349$ & 2,509 & $0,724 \times 0,531$ & 0,384 \\
\hline 1 & 113 & $0,372 \times 0,27$ & 0,1 & $0,144 \times 0,106$ & 0,015 \\
\hline
\end{tabular}

блиця 8

ля м триці «1/1,8”» фокусн відст нь $f=2$ см

\begin{tabular}{|c|c|c|c|c|c|c|c|c|}
\hline \multirow{2}{*}{$\begin{array}{l}H, \\
\mathrm{KM}\end{array}$} & \multicolumn{2}{|c|}{ триця 3} & \multicolumn{2}{|c|}{ триця 4} & \multicolumn{2}{|c|}{ триця 5} & \multicolumn{2}{|c|}{ триця 8} \\
\hline & $R, \mathrm{M}$ & $R, \mathrm{M}$ & $R, \mathrm{M}$ & $R, \mathrm{M}$ & $R, \mathrm{M}$ & $R, \mathrm{M}$ & $R, \mathrm{M}$ & $R, \mathrm{M}$ \\
\hline 90 & 16,2 & 24,3 & 13,95 & 20,7 & 12,6 & 18,45 & 9,9 & 14,85 \\
\hline 80 & 14,4 & 21,6 & 12,4 & 18,4 & 11,2 & 16,4 & 8,8 & 13,2 \\
\hline 70 & 12,6 & 18,9 & 10,85 & 16,1 & 9,8 & 14,35 & 7,7 & 11,55 \\
\hline 60 & 10,8 & 16,2 & 9,3 & 13,8 & 8,4 & 12,3 & 6,6 & 9,9 \\
\hline 50 & 9 & 13,5 & 7,75 & 11,5 & 7 & 10,25 & 5,5 & 8,25 \\
\hline 40 & 7,2 & 10,8 & 6,2 & 9,2 & 5,6 & 8,2 & 4,4 & 6,6 \\
\hline 30 & 5,4 & 8,1 & 4,65 & 6,9 & 4,2 & 6,15 & 3,3 & 4,95 \\
\hline 20 & 3,6 & 5,4 & 3,1 & 4,6 & 2,8 & 4,1 & 2,2 & 3,3 \\
\hline 10 & 1,8 & 2,7 & 1,55 & 2,3 & 1,4 & 2,05 & 1,1 & 1,65 \\
\hline 5 & 0,9 & 1,35 & 0,775 & 1,15 & 0,7 & 1,025 & 0,55 & 0,825 \\
\hline 1 & 0,18 & 0,27 & 0,155 & 0,23 & 0,14 & 0,205 & 0,11 & 9,165 \\
\hline
\end{tabular}

ля м триці «1/1,8”'» фокусн відст нь $f=5$ см

блиия 9

\begin{tabular}{|c|c|c|c|c|c|c|c|c|}
\hline \multirow{2}{*}{$\begin{array}{l}H, \\
\text { км }\end{array}$} & \multicolumn{2}{|c|}{ триця 3 } & \multicolumn{2}{|c|}{ триця 4 } & \multicolumn{2}{|c|}{ триця 5} & \multicolumn{2}{c|}{ триця 8} \\
\cline { 2 - 8 } & $R, \mathrm{M}$ & $R, \mathrm{M}$ & $R, \mathrm{M}$ & $R, \mathrm{M}$ & $R, \mathrm{M}$ & $R, \mathrm{M}$ & $R, \mathrm{M}$ \\
\hline 90 & 6,48 & 9,72 & 5,58 & 8,28 & 5,04 & 7,56 & 3,96 \\
\hline 80 & 5,76 & 8,64 & 4,96 & 7,36 & 4,48 & 6,72 & 3,52 \\
\hline 70 & 5,04 & 7,56 & 4,34 & 6,44 & 3,92 & 5,88 & 3,08 & 4,62 \\
\hline 60 & 4,32 & 6,48 & 3,72 & 5,52 & 3,36 & 5,04 & 2,64 & 3,96 \\
\hline 50 & 3,6 & 5,4 & 3,1 & 4,6 & 2,8 & 4,2 & 2,2 & 3,3 \\
\hline 40 & 2,88 & 4,32 & 2,48 & 3,68 & 2,24 & 3,36 & 1,76 & 2,64 \\
\hline 30 & 2,16 & 3,24 & 1,86 & 2,76 & 1,68 & 2,52 & 1,32 & 1,98 \\
\hline 20 & 1,44 & 2,16 & 1,24 & 1,84 & 1,12 & 1,68 & 0,88 & 1,32 \\
\hline 10 & 0,72 & 1,08 & 0,62 & 0,92 & 0,56 & 0,84 & 0,44 & 0,66 \\
\hline 5 & 0,36 & 0,54 & 0,31 & 0,46 & 0,28 & 0,42 & 0,22 & 0,33 \\
\hline 1 & 0,072 & 0,108 & 0,062 & 0,092 & 0,056 & 0,084 & 0,044 & 0,066 \\
\hline
\end{tabular}

() . . шков, . . улеко, . . ум кевич 
н лізу н ведених результ тів моделюв ння виплив $\epsilon$, що використ ння суч сних цифрових фото п р тів, н віть не д птов них спеці льно до рішення з д ч розвідки, цілком можливе н висот $\mathrm{x}$ до $10 \mathrm{KM.}$

трим н для висот до 10 км розрізнюв льн зд тність при $f=5$ см дозволяє розпізн в ти н віть до окремого солд т . лід зв ж ти н те, що отрим ні результ ти оцінки розрізнюв льної зд тності приблизні i не вр ховують низку шкідливих ф кторів, які нег тивно вплив ють н знімок: вплив тмосфери, тремтіння знім льн ої системи тощо.

ля рішення 3 д ч розвідки необхідно використовув ти об'єктиви з довгим фокусом 5 см і більше.

\section{ИСНОВ К И}

ким чином, ефективне пл нув ння т 3 стосув ння р кетно- ртилерійського озброєння вим г ють якісного розвідув льно-інформ ційного з безпечення, що може досяг тися лише 3 р хунок інтегр ції в єдиних втом тизов них систем $\mathrm{x}$ різних з собів розвідки, ур ження т упр вління.

фективність ведення ртилерійської розвідки може бути зн чно підвищен 3 р хунок використ ння в якості дод ткового джерел інформ ції р кетно- ртилерійських космічних комплексів.

икорист ння р кетно- ртилерійських космічних комплексів, прототипом яких є проект « окіл», для ведення ртилерійської розвідки можливе, одн к при цьому доцільно корегув ти висоту виведення зонд (не більше 10 км).

д пт ція т ких систем до ведення ртилерійської розвідки потребує под льших досліджень.

\section{писок літер тури}

1. іл книг 2008: оборонн політик кр їни. - .. іністерство оборони, 2009. - $100 \mathrm{c}$.

2. лотов . . изн чення координ т орієнтирів $m$ цілей цифровим стереофотогр мметричним методом / . . лотов // еодезія, к ртогр фія $i$ ерознім ння. 2005. - un. 60. - .102-106

3. обров . . диолок ционн я ст нция

-10: чебно-методическое пособие / [ обров . ., ыхнов . ., емин . .J. - .. , 1981. - 341 с.

4. шков . . етодологія розробки псевдосупутникових систем як скл дних технічних систем / . . шков, . . улеко, . . ум кевич // истемні технології. егіон льний міжвузівський зб. н ук. $п р$ ць. 2007. - un. 6(4). - .172-188.

5. ерж вне київське конструкторське бюро « уч» [ лектронний ресурс]: www.luch.kiev.иа.

6. ебедев. . осмические системы н блюдения: интез и моделиров ние / . . ебедев, . . естеренко.-М.: шиностроение, 1991. -224 c.

7. урье . . еория и пр ктик цифровой обр ботки изобр жеений / ист нционное зондиров ние и геогр фические информ иионные системы // . . урье, . . осиков; под ред. А. М. ерлянт . - .. у учный мир, 2003. - .8.

8. ртюшин . . стосув ння сил $i$ з собів повітряної розвідки н земного противник у суч сних опер ціях $і$ воєнних конфлікт х/. . ртюшин, . . осов // руди к демії. - 2000. - № 24. - .26-80.

9. ртюшин . . ерокосмічн розвідк в лок льних війн х суч сності: досвід, проблемні пит ння і тенденції / . . ртюшин, . . осов, . . 'ясковський, . . олубко. - .. ,2002. - .208-212.

дійшл до ред кцї̈ 2.12.2008

ецензент: доктор технічних н ук, ст рший н уковий співробітник . . убков, ьвівський інститут ухопутних військ, ьвів.

. . шков, . . улеко, . . ум кевич

ссм трив ются способы использов ния ртиллерийских систем для з пуск псевдоспутниковых систем н блюдения, требов ния и свойств их пn р туры.

лючевые слов : ртиллерийск я р зведк, псевдоспутников я систем, зон обзор, избир тельн я способность, фото nn p myp.

\title{
AN ANALYSIS OF POSSIBILITIES OF APPLICATION OF ROCKET-ARTILLERY PSEUDOSPACE COMPLEXES IS DURING THE CONDUCT OF ARTIL LERY RECONNAISSANCE
}

\author{
O. A. Mashkov, I. V. Puleko, V. O. Chumakevich
}

The methods of the use of the artillery systems for the launch of the pseudosatellite systems of surveillance, requirements and properties of their equipment are examined.

Keywords: artillery reconnaissance, pseudosatellite system, surveillance zone, ability to distinguish, photoequipment. 